\title{
Depremden Etkilenen Betonarme Konutların Onarım/Yıkım Karar Sürecine Maliyetlerin Etkisi
}

\author{
Sinan GÜNEŞ1, Metin ARSLAN²
}

\begin{abstract}
Özet
Çalışmanın amacı; depremden etkilenmiş ve hasar görmüş betonarme konutların onarım/yıkım karar sürecinde hasar tür ve seviyeleri ile maliyet faktörleri analizinin yapılarak en etkin ve ekonomik karara ulaşılmasındaki alternatif yaklaşımları analiz ederek en uygun yaklaşımı belirlemektir. Çalışmada 2011 Van depreminden etkilenen 270 betonarme konut incelenmiş ve hasar türleri; taşıyıcı ve taşıyıcı olmayan elemanlarda görülen çatlaklar, ezilmeler, dökülmeler, ayrılmalar ve göçmeler olarak, hasar seviyeleri ise hasarsız, az, orta, ağır hasarlı ve yıkık olarak sınıflandırılmıştır. Onarım tür ve maliyet yönteminde yapısal hasarlar, onarım ve güçlendirme ile acil barınma maliyetleri ve yaralanma ile ölüm gibi insani kayıplar ele alınmıştır. Yıkım tür ve maliyetlerinde yapı söküm tekniğine göre şantiye kurulumu, iş̧̧ilik, ekipman, nakliye ve tasfiye maliyet analizleri yöntem olarak seçilmiştir. Karar aşamasında güçlendirme yöntemlerine göre belirlenen alternatiflerin iç verim oranı, kârlılık endeksi ve geri ödeme süreleri yönlerinden karșılaștırmalı analizi yapılmıștır. Çalıșmada yeniden yapım, yapının olduğu gibi bırakılması, zemin kat güçlendirme ve tüm kat güçlendirme olmak üzere dört alternatif belirlenmiş olup, zemin kat güçlendirmesi tüm karşlaş̧tırma parametreleri bakımından en uygun seçenek olmuştur. Türkiye'de güçlendirme uygulamalarında sıkça rastlanılan $\% 40$ maliyet oranının tek başına karar sürecinde değerlendirilmesi ve sabit bir oran olarak kullanılmasının gerçekçi sonuçlar vermekten uzak olacağı görülmüştür.
\end{abstract}

\section{Effect of Costs on the Repair / Demolition Decision Process of Reinforced Concrete Houses Affected by Earthquake}

\begin{abstract}
The aim of the study is; To determine the most appropriate approach by analyzing alternative approaches in reaching the most effective and economical decision by analyzing the types and levels of damage and cost factors in the repair / demolition decision process of the reinforced concrete houses affected and damaged by earthquakes. In the study, 270 reinforced concrete houses affected by the 2011 Van earthquake were examined and types of damage; Damage levels such as cracks, crushes, spills, separations and collapses seen in bearing and non-bearing elements are classified as undamaged, low, medium, severely damaged and collapsed. In the method of repair type and cost, structural damages, repair and reinforcement, emergency housing costs, and humanitarian losses such as injury and death are discussed. In terms of demolition types
\end{abstract}

\footnotetext{
1 Öğretim Görevlisi, Ankara Üniversitesi, Uygulamalı Bilimler Fakültesi, Gayrimenkul Geliștirme ve Yönetimi Bölümü, Ankara İlgili yazar e-posta / Corresponding author e-posta: sinan.gunes@ankara.edu.tr ORCID No: 0000-0001-7753-8333

2 Profesör, Ankara Üniversitesi, Uygulamalı Bilimler Fakültesi, Gayrimenkul Geliştirme ve Yönetimi Bölümü, Ankara e-posta: metinarslan@ankara.edu.tr ORCID No: 0000-0002-5000-1226
} 
and costs, construction site installation, labor, equipment, transportation and liquidation cost analysis were chosen as methods according to the dismantling technique. Comparative analysis of the alternatives determined according to the strengthening methods at the decision stage was made in terms of internal rate of return, profitability index and payback periods. In the study, four alternatives were determined: reconstruction, leaving the structure as it is, ground floor strengthening and whole floor reinforcement, and ground floor reinforcement was the most suitable option in terms of all comparison parameters. The evaluation of the stand-alone decision-making process frequently encountered in strengthening practice in Turkey and $40 \%$ cost ratio would be far from realistic results when used as a fixed rate has been determined.

Keywords: Earthquake, Damaged Structure, Damage Type, Damage Level, Construction Cost, Cost-Benefit Analysis

\section{GİRIŞ}

Türkiye sismotektoniği incelendiğinde hasarlı ve yüzey kırığı oluşturan büyük deprem kayıtlarının M.Ö. 2000 yıllarına kadar uzandığı tespit edilmiştir. 1900-1995 döneminde bu türden 118 adet deprem kaydına rastlanılmaktadır. Geçmişten günümüze süregelen depremler Türkiye'de ekonomik, sosyal, hukuksal ve yapısal birçok faaliyet alanında etkisini göstermiş ve söz konusu alanlarda değişimlere neden olmuştur. Bu durum ülke sınırları içinde inşa edilecek yapıların tasarımında da önemli bir değişken olarak ele alınmıştır. Özellikle 1999 yılında meydana gelen Marmara Depremi'nde ortaya çıkan yaklaşık 10-13 milyar \$ düzeyindeki finansal yük ekonomik anlamda deprem gerçeğine dikkatleri çekmiştir (Elibol, 2001; Güneş, 2018). Bu ekonomik kayıplara insan hayatının da eklenmesi neticesinde deprem gerçeğine karşı önlem alınması hem ekonomik hem de insani açıdan zorunlu hale gelmektedir.

Mevcut durumda çevresel etkiler ve projelendirme veya uygulama hatalarından kaynaklanan yapısal kusurlar gibi çeşitli sebeplerle hasar gören binalara kentsel dönüşüm gibi uygulamalarla yıkım kararı verilmesi ya da onarılması sık rastlanan uygulamalardır. Onarım veya yıkım kararları verilmesini gündeme taşıyan bir diğer konu ise deprem riskidir. Türkiye'de deprem riskinin yüksek olması nedeniyle, hasarlı binalarda onarım veya yıkım kararı verilmesi giderek yaygınlaşmakta ve inşaat sektörünün öncelikli projeleri hakkında ilk sıralara yükselmektedir. Betonarme binaların onarımına veya yıkımına karar verilebilmesi için öncelikle detaylı bir maliyet analizi yapılmalıdır. Literatürde her ne kadar depreme dayanıklı yapı tasarımına ve uygulama aşamasında yaygın olarak kullanılan yapım tekniklerine ilişkin birçok çalışma yer alsa da genelde maliyet analizi ve özelde hasarlı yapıların güçlendirilmesi ve onarımına yönelik az sayıda çalışmaya rastlanması, bu alandaki boşluğu göstermektedir. Bununla birlikte her bir betonarme bina tasarımının kendine has özelliklerinin bulunması, maliyet analizi açısından genelleme yapılmasını olanaksız kılmaktadır. Bu nedenle onarım/yıkım kararı öncesi, maliyet ve ekonomik analizlerin yapılmasına ve yol gösterici araştırmalara ihtiyaç duyulmaktadır. Depremden etkilenen hasarlı konutlar ile ilgili yıkım veya onarım kararını verecek ilgili idarenin, müteahhit veya bina sahibi gibi kişi ve kurumlara rehberlik etmesine de gereksinim duyulmaktadır.

Bu çalışmanın amacı; depreme maruz kalmış ve bu depremde hasar görmüş betonarme konut niteliğindeki yapıların onarımına/yıkımına karar vermede hasar tür ve seviyeleri ile maliyet unsurlarının analiz edilerek en etkin ve ekonomik karara ulaşılmasına ilişkin yaklaşımların genel anlamda ve saha çalışmasının gerçekleştirildiği Van Kenti örneği üzerinden belirlenmesidir. Saha çalışması aşamasında hem ilgili kamu kurum/kuruluşları tarafından oluşturulan hasar tespit komisyonlarının çalışma sonuçları, hem de konu ile ilgili yargı kararları kapsamlı olarak incelenmiş ve temel sorun alanlarının tespiti yapılmıştır. Çalışma sonuçlarına göre özellikle mesken nitelikli betonarme binalar için genelleme yapılması yoluna gidilmiş olup, saha çalışmasının tek bir yerleşim yerinde olması ve sınırlı sayıda binayı kapsaması da dikkate alınarak sonuçların genelleştirilmesinde ihtiyatlı olunmasına özen gösterilmiştir. 
Çalışma ana hatları ile kuramsal bir çerçeveye dayandırılmış olup, depremden etkilenen betonarme konutlarda onarım veya yıkım kararının maliyetler açısından incelenerek karar sürecine katkı sağlaması olanakları tartışılmıştır. Türkiye'nin, deprem kuşağında yer alması ve depremin tarih boyunca oluşturduğu yıkıcı etkiler göz önüne alınarak depremin önemi ortaya konulmuş olup, diğer doğal afetler ve yapı stokunu etkileyen etmenler kapsam dişı bırakılmıştır. Çalışma kapsamında depremde hasar gören yapılar arasında en fazla sayıda etkilenen yapı türünün betonarme konutlar olması nedeniyle saha çalışmasında betonarme konutlar ele alınmış ve diğer yapı türleri incelemenin kapsamı dışında bırakılmıştır. Depremden etkilenen betonarme konutların onarım veya yıkım kararının verilmesinin literatür çalışmalarında yer almaması, mevcut uygulamalarda karar verme sürecinin sağlıklı yürütülememesi ve halen yürürlükte olan mevzuat hükümlerinin yetersizliği gibi nedenlerle onarım veya yıkım kararı verilmesi durumu analiz edilmiş ve riskli yapılarda hesaplanan güçlendirme ya da yıkım kararlarının tartışılması çalışma kapsamı dışında bırakılmıştır.

Çalışma sürecinde depremden etkilenen betonarme konutlarda onarım veya yıkım kararı verilebilmesi için yapı maliyetlerinden yararlanılmıştır. Karar sürecinin maliyet açısından incelenmesi sırasında metraj keşif, malzeme seçimi, yapı elemanları maliyeti ile yeniden yapım yaklaşık maliyetleri kullanılmıştır. Onarım ve yıkım süreçleri afet öncesi, afet anı ve afet sonrası olarak üç bölümde incelenmekte ve her bir süreç betonarme konutlar için kendine has maliyetleri de beraberinde getirmektedir. Çalışma kapsamında afet anında ve sonrasındaki süreçte meydana gelebilen maliyetler dikkate alınarak karar verme süreçlerine ilişkin analiz ortaya konulmuştur.

Önceki deprem sonuçlarının sayısal olarak kayıtlara alındı̆̆ı, ancak kapsamlı ekonomik, sosyal, mekânsal ve çevresel analizlerin yapılmadığı görülmektedir. Oysa muhtemel felaketlerin önlenebilmesi veya etkilerinin en aza indirilebilmesi için önceki deneyimlerden alınan dersler, yöntemlerin geliştirilmesine duyulan ihtiyaç, her yıkıcı deprem sonrası daha şiddetli bir şekilde ortaya çıkmaktadır. Bu tür yenilikçi yaklaşımlardan biri de depremden etkilenen veya hasarlı yapıların güçlendirme ve yıkım kararlarının verilmesine yönelik teknik ve ekonomik araştırma sonuçlarına dayalı karar modellerinin geliştirilmesi ve etkin olarak uygulanması olduğu görülmektedir.

Çalışma konusu ile ilgili yol gösterici nitelikte olan literatür altyapısının Türkiye'de henüz yeni sayılabilecek araştırma ve çalışmalardan oluştuğu görülmektedir (İncir vd., 2016; Alku, 2005; Arıkan vd., 2005; Boylu, 2005; Coelho ve Brito, 2011; Doğan, 2013; Kusar vd. 2013; Yanmaz ve Luş, 2005; Pun, Liu ve Langston, 2006; Yılmaz, 2016; Yılmaz vd., 2018). Güçlendirme uygulamalarının ekonomik yönden incelendiği çalışmalarda fayda-maliyet analizi yöntemlerinin öne çıtığı (Boylu, 2005; Kusar vd. 2013; Yanmaz ve Luş, 2005) ve başlıca maliyet kalemlerinin ise insani kayıplar, yapıda barınan insan sayısı, faiz oranı, bina yaşı, bina yaşam döngüsü maliyetleri ve yapısal güvenlik kriterleri olduğu ifade edilmiştir (Doğan, 2013; Kusar vd. 2013; Yanmaz ve Luş, 2005). Bu kapsamda betonarme bir konut için yapılması gereken güçlendirme çalışmaları detaylı olarak incelenmekle birlikte ekonomik fizibilite analizlerinin gerek teoride gerekse uygulamada yetersiz düzeyde kaldığı, uygulanan fizibilite çalışmalarının ise gerçekçi tahmin ile detaylı veriler içermediği ve onarım/yıkım kararı sürecinde en etkili parametrelerden biri olan maliyet analizlerinin daha detaylı biçimde yapılması gerektiği ortaya çıkmaktadır.

\section{MATERYAL VE YÖNTEM}

Betonarme bir konuta ilişkin onarım/yıkım kararı verilebilmesi için öncelikle onarım ve maliyet kıstaslarının belirlenmesi gerekli olmaktadır. Bu kapsamda kaynak araştırmalarında kullanılan yöntemler incelenmiş olup, güçlendirme modelinin oluşturulabilmesi için öncelikli olarak yapı güvenliğinin test edilmesi gerektiği ortaya çıkmıştır. Yapı güvenliğinin sağlanabilmesi için; binanın deprem hareketine gösterdiği tepkinin, yapıların bulunduğu bölgedeki yerel zemin 
özellikleri ile inceleme konusu binanın özgün niteliklerinin bilinmesi gereklidir (Kusar vd. 2013; Yılmaz 2016). Bu kapsamda çalışma alanı özellikleri de göz önünde bulundurularak yapı projesinde yönetmelik hükümleri ile alt ve üst sınırlar dikkate alınarak teknik veriler belirlenmiştir. Fayda-maliyet analizi aşamasında betonarme konutlarda yaygın olarak ortaya çıkan maliyet kalemleri; taşıyıcı elemanların maliyetleri, taşıyıcı olmayan elemanların maliyetleri, yapı içeriği maliyetleri, acil barınma ve güçlendirme maliyetleri ile insani kayıplar (ölümler ve yaralanmalar) olmak üzere beş başlık altında sınıflandırılmıştır. Hesaplanan fayda ve maliyet kalemlerinin onarım yıkım kararında etkin olarak kullanılabilmesi için ise söz konusu fayda ve maliyetlerin net bugünkü değer analizi, iç verim oranı, fayda/maliyet oranı ve geri ödeme süresi yönlerinden analiz edilmiştir. Bu veriler ışığında alternatifler karşılaştırılarak en uygun projenin belirlenmesi sağlanmıștır.

\subsection{Hasar Türlerinin Belirlenmesi}

Çalışmada öncelikle betonarme binalarda hasar oluşumuna neden olan etkenler yapılan literatür taraması neticesinde belirlenmiştir (Yakut vd., 2011; Güney, 2011; TMMOB Mimarlar Odası, 2012; Yllmaz ve Umu, 2017; Grünthal, 1998; Baggio vd., 2007; Birand, 2007; Kaminosono vd., 2002; Yüksel, 2008). Buna göre söz konusu etkenler; yetersiz etriye kullanımı ile yetersiz donatı detayı, kritik bölgelerde yetersiz etriye sıklaştırılması ile deprem etriyesi/çiroz kullanılmaması, düz donatı kullanımı, zemin katların bölme/perde duvar kullanılmaksızın dükkân olarak kullanımı, işçilik ve malzemede kalitesizlik, fazla kat çıkılmasına bağlı olarak zemine hesaplanandan fazla yük bindirilmesi ya da zemin hareketlerinin farklılaşması, deprem bölgelerinde kullanımına izin verilmeyen beton sınıfı kullanımı, kolon-kiriş birleşim yerlerinde güçlü kiriş-zayıf kolon etkisi, yanal rijitlik sağlayan perdelerin bulunmayıșı, kolonda plastik mafsal etkisi, yumuşak kat oluşumu, kirişsiz döşemelerin varlığı, hatalı temel seçimi neticesinde yapıya gelen sabit/hareketli yüklerin artması olarak sıralanabilir.

Deprem sonrası yayımlanan bilimsel ve teknik raporlar (Yakut vd., 2011; Güney, 2011), ilgili kurum/kuruluşlardan alınan veriler (TMMOB Mimarlar Odası, 2012) ve yerinde yapılan kapsamlı gözlem ve saha çalışmaları neticesinde hasarlı yapılarda tespit edilen eksik ve hatalı imalat kalemleri birlikte değerlendirilerek yapıda meydana gelen hasar türleri gruplandırılmıştır. Buna göre hasar grupları; sıva çatlakları ve sıva ile boya tabakalarında dökülmeler, dolgu ve taşıyıcı duvarlarda çatlaklar, taşıyıcı elemanlarda meydana gelen çatlaklar, bölme ve taşıyıcı duvarlarda gözlemlenen ayrılmalar, genişliklerine göre taşıyıcı elemanlarda gerçekleşen çatlaklar ve ayrılmalar, bina köşelerinde ayrılma ve ezilmeler, taşıyıcı elemanlarda kesme kuvvetinden dolayı meydana gelen ayrılmalar, konik biçimli dökümeler, bölme ve taşıyıcı duvarlarda tamamen veya kısmen göçmeler ve taşıyıcı elemanlarda kısmen veya tamamen göçmeler şeklinde belirlenmiştir.

\subsection{Hasar Seviyelerinin Belirlenmesi}

Binalarda taşıyıcı ve taşıyıcı olmayan sistem elemanları için literatürde öngörülen sınıflandırmalar ve yasal hasar sınıflandırmaları birlikte değerlendirilerek hasar seviyeleri yeniden gruplandırılmıştır (İncir vd., 2016; Yakut vd., 2011; Güney, 2011; TMMOB Mimarlar Odası, 2012; Baggio vd. 2007; Kaminosono vd. 2002). Betonarme binalarda gözlemlenen hasar türleri çalışma kapsamında kriterler kümesi halinde hasar seviyelerinin sınıflandırılmasında kullanılmıştır. Buna göre her bir hasar türü, hasar seviyesi olarak belirlenen hasarsız, az hasarlı, orta hasarlı, ağır hasarlı ve yıkık kategorileri içinde temsil edilmiştir.

Yapıya ilişkin hasar tespit formu doldurulurken idari bilgiler bölümünde; mülkiyet durumu mal sahibi, kiracı ve hisseli olarak, plan geometrisi dikdörtgen/kare veya diğer geometri (zemin katta duvar simetrisi yok), kullanım amacı konut, depo, ahır, samanlık, ticarethane, metruk ve resmi bina olarak sınıflandırılmış olup, ayrıca kat adedi ve bina konum bilgileri $(0,1,2,3,1+1)$ de şekil üzerinde tarif edilmiştir (İncir vd., 2016). Buna göre taşıyıcı olmayan sistem elemanlarında hasar seviyeleri; 
- Hasarsız (0); doğal afet nedeniyle herhangi bir hasar görmeyen yapı,

- Az hasarlı (2); ince sıva çatlakları, sıva dökülmeleri, duvarlarda 1-4 mm genişlikte ince çatlaklar, dolgu ve kalkan duvarlarda 10 mm'ye kadar çatlaklar ve kısmi dökülmeler,

- Orta hasarlı (4); taşıyıcı elemanlarda 5-10 mm genişlikte önemli çatlaklar, bölme, dolgu ve kalkan duvarlarda kısmi yıkılma ve ayrılmalar,

- Ağır hasarlı (6); taşıyıcı elemanlarda 10 mm'den geniş ve yaygın kesme kırılmaları bina köşelerinde ayrılma ve ezilmeler, konik biçimde dökülmeler, binanın düşeyden ayrılması, bölme, dolgu ve kalkan duvarlarda kısmen veya tamamen yıkılmalar,

- Yıkık (8); bina taşıyıcı sisteminde kısmen veya tamamen yıkılmalar, çatının kısmen veya tamamen göçmesi olarak tanımlanmıştır.

Merdiven elemanlarında hasar seviyeleri 0: hasarsız ve 1: çatlama veya göçme var olarak 2 grupta incelenmektedir. Çatılarda ise hasar seviyeleri hasarsız, az hasarlı, orta hasarlı ve ağır hasarlı/yıkık olarak dört başlık altında irdelenmektedir. Hasar seviyelerinin açıklamalarında ise;

- Hasarsız (0); çatıda afet nedeniyle meydana gelmiş herhangi bir hasarın tespit edilemediği durum,

- Az hasarlı (2); 20 mm'ye kadar tek çatlak; 5 mm'ye kadar çok sayıda çatlak; birçok kiremidin ve çatı levhalarının yerinden oynaması,

- Orta hasarlı (4); bacaların yıkılması, çatı malzemelerinin oynaması; 20 mm'den geniş çatlaklar, 5-20 mm çok sayıda çatlama; levhaların ve aşıkların oynaması

- Ağır hasarlı/Yıkık (6); ahşap taşıyıcı elemanların yerinden çıkması, kısmi göçme, duvarlardan ayrılma, makas ve diğer taşıyıcı kısımların yerinden çıkması; yaygın göçmeler, çatının kısmen veya tamamen aşağı inmiş hali olarak belirlenmiştir.

\section{3. Örneklem Seçimi}

23 Ekim-9 Kasım 2011 Van-Edremit Depremlerine ilişkin binaların hasar tespit formları T.C. Van Valiliği İl Afet ve Acil Durum Müdürlüğü'nden edinilmiştir. Depremin yoğun olarak etki ettiği Alipaşa ve Bahçıvan Mahallelerinde bulunan binaların tespit formları arasından, betonarme konutların tespit formları alınarak bu binalara ait hasar seviyeleri incelenmiş olup binaların konumları Şekil 1'de görülmektedir.

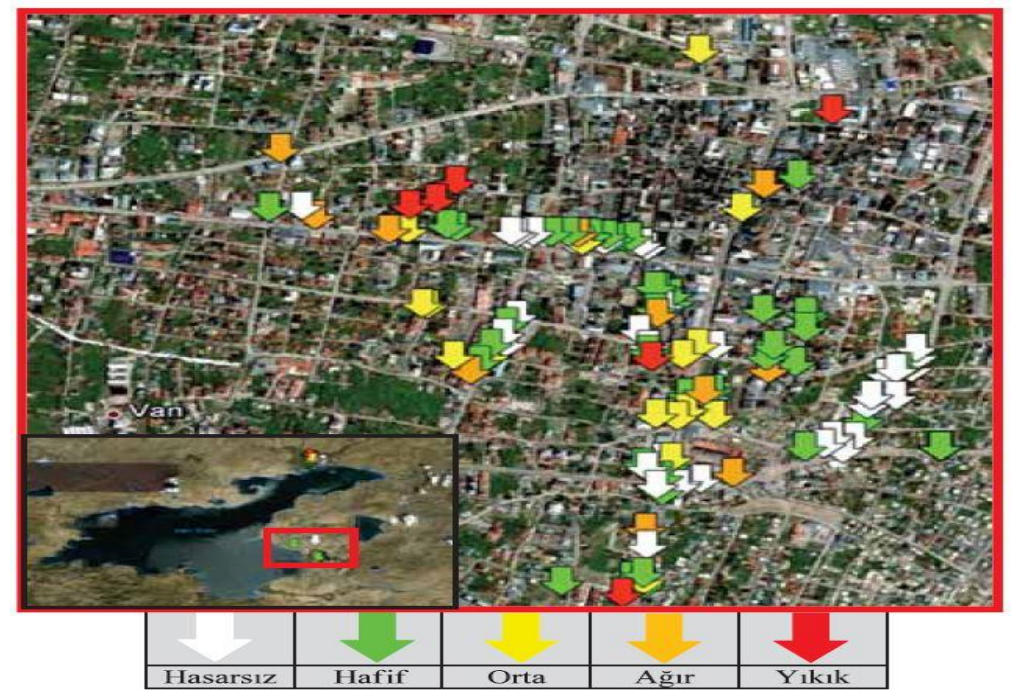

Şekil 1. Alipaşa ve Bahçıvan Mahallelerinde incelenen bina konumları

Çalışma konusu mahallelere iliş̧in elde edilen verilerin anlamlı bir sonuç oluşturması ve bölgede yapılmak istenen onarım/güçlendirme veya yıkım kararlarına altlık teșkil etmesi amacıyla belirli kriterler göz önüne alınarak sınıflandırma yoluna gidilmiştir. Öncelikle yapım tekniklerinin 
yürürlükteki deprem yönetmeliği dikkate alınarak geliştirildiği ve uygulandığı dikkate alınarak Türkiye'de uygulamaya konulan deprem yönetmeliklerinin yürürlüğe giriş yılları olan 1998, 2007 ve sonrası yıllar, veri setindeki binaların inşa edilme yıllarında gruplandırılarak dikkate alınmıştır. Verilerin analiz edilmesinde dikkate alınan bir diğer husus ise betonarme binaların kat adetleri olmuştur. Yerinde yapılan saha gözlemlerinde betonarme binaların statik ve mimari projesinde öngörülen kat adetleri ile sınırlı kalmadı̆̆ı, yapılara hesaplanandan daha fazla yük yüklendiği tespit edilmiş olup, söz konusu kriterin yapılarda meydana gelebilecek hasar türlerine doğrudan etki ettiği öngörülmüştür. Bu kapsamda incelenen yapıların özellikleri dikkate alınarak Tablo 1'de gösterildiği gibi yapılar 9 ayrı grupta sınıflandırılmış ve her grup kodu için 30 adet betonarme taşıyıcı sistem konut niteliğinde bina hasar türleri ve seviyeleri yönlerinden incelenerek onarım/güçlendirme veya yıkım kararı sürecinde ele alınmıştır.

Tablo 1. Yapım yılları ve kat adetlerine göre bina sayıları

\begin{tabular}{cccc}
\hline \multirow{2}{*}{ Yapım Yilı } & \multicolumn{3}{c}{ Kat Adedi } \\
\cline { 2 - 4 } & $2-5$ Kat (1. Grup) & 6-7 Kat (2. Grup) & 8-10 Kat (3. Grup) \\
\hline $\mathbf{1 9 9 8}$ (A Grubu) & 25 & 61 & 16 \\
\hline $\mathbf{1 9 9 9 - 2 0 0 6}$ (B Grubu) & 7 & 48 & 13 \\
\hline $\mathbf{2 0 0 7 - 2 0 1 1 ~ ( C ~ G r u b u ) ~}$ & 2 & 15 & 22 \\
\hline
\end{tabular}

Hasar seviyeleri ile türleri, onarım/güçlendirme-yıkım maliyetlerinde gruplandırma yapılarak hesaplamalarda kolaylık sağlamak ve daha anlaşılabilir sonuçlar ortaya koyabilmek amacıyla Tablo 2'de gösterildiği gibi binalarda yapım yılı ve kat adetlerine göre sınıflandırma yoluna gidilmiştir.

Tablo 2. Yapım yılı ve kat adedine göre binaların sınıflandırılması

\begin{tabular}{|c|c|c|c|}
\hline $\begin{array}{l}\text { Grup } \\
\text { Kodu }\end{array}$ & Yapım Yılı & Kat Adedi & Çatı Tipi \\
\hline A1 & \multirow{3}{*}{ 1972-1998 } & $2-5$ & \multirow{3}{*}{ Galvanizli sac suni elyaf, beton } \\
\hline A2 & & $6-7$ & \\
\hline A3 & & $8-10$ & \\
\hline B1 & \multirow{3}{*}{ 1999-2006 } & $2-5$ & Galvanizli sac suni elyaf, beton \\
\hline B2 & & $6-7$ & Galvanizli sac suni elyaf, beton \\
\hline B3 & & $8-10$ & Galvanizli sac suni elyaf \\
\hline C1 & \multirow{3}{*}{$2007-2011$} & $2-5$ & Galvanizli sac suni elyaf \\
\hline $\mathrm{C} 2$ & & $6-7$ & Galvanizli sac suni elyaf, beton \\
\hline C3 & & 8-10 & Galvanizli sac suni elyaf, beton \\
\hline
\end{tabular}

\subsection{Hasar Seviyelerinin Onarım ve Yıkım Açısından Analizi}

Betonarme binalarda onarım veya güçlendirme yöntemleri için Türkiye Bina Deprem Yönetmeliği (TBDY) hükümleri dikkate alınarak onarım ve/veya güçlendirme alternatifleri belirlenmiştir. Yönetmelik hükümleri uyarınca öncelikle onarım/güçlendirme yapılması planlanan betonarme binadan hasara ilişkin bilgi toplama işleminin yapılması gerekmektedir. Mevcut binaların taşıyıcı sistem elemanlarının kapasitelerinin belirlenmesinde ve deprem dayanımlarının değerlendirilmesinde kullanılacak eleman detayları ve boyutları, taşıyıcı sistem geometrisine ve malzeme özelliklerine ait bilgilerin, bina projeleri ile hasar tespit raporlarından, ölçüm ve gözlemler ile uygun malzeme deneylerinden edinilmesi gerekmektedir. Çalışma konusu Van Depremlerinin üzerinden uzun zaman geçmesi ve yerinde tespit yapma imkânının bulunmaması nedenlerinden dolayı söz konusu veriler, depremden hemen sonra bölgede hasar tespitinde bulunan Üniversite raporları ve resmi kaynaklardan elde edilmiştir (Yakut vd., 2011; Güney, 2011; TMMOB Mimarlar Odası, 2012). Şekil 2'de güçlendirme tip projesi ve takviye detayları belirlenen binaların Van ili bölgesel şartları dikkate alındığında;

- Zemin grubu; C grubu zeminler 
- Yerel zemin sınifi; Z3 $15 \mathrm{~m}<\mathrm{h} 1 \leq 50 \mathrm{~m}$ olan (C) grubu zeminler

- Etkin yer ivmesi katsayısı (A0); 0,40

- Bina önem katsayısı; 1,0

- Spektrum karakteristik periyotları Z3 yerel zemin sınıfı için TA; 0,15 sn ve TB; 0,60 sn

- Taşıyıcı sistem davranış katsayısı 4

- Hareketli yük katılım katsayısı (n); 0,30

- Beton dayanım sınıfı C25, nervürlü çelik dayanım sınıfı S420 verilerine göre hesaplanmıştır.
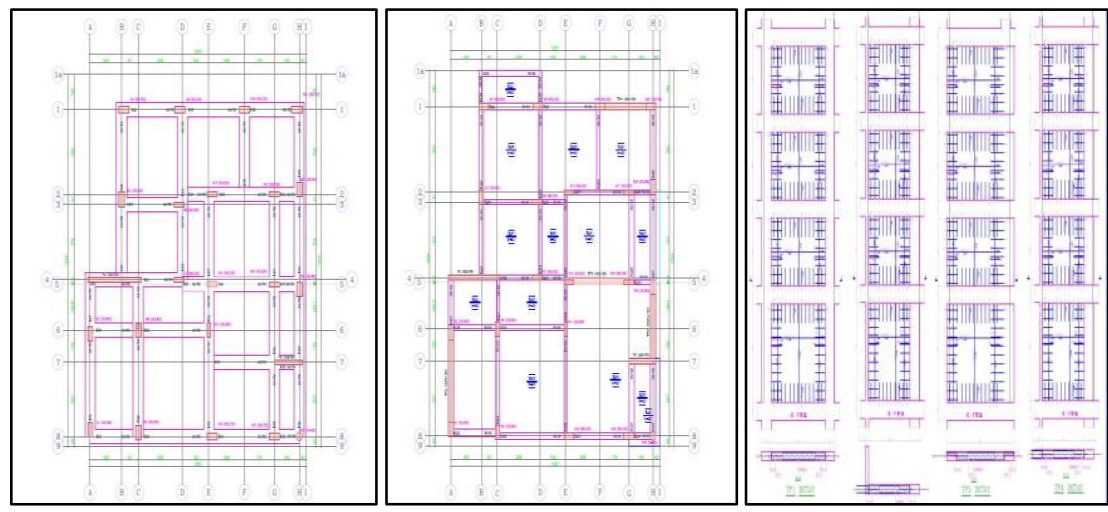

Şekil 2. Tip proje ve güçlendirme detayları

\subsection{Onarım Türü ve Maliyetleri}

En uygun onarım/güçlendirme veya yıkım kararı verilebilmesi için karar sürecinde kullanılmak üzere inceleme konusu alanda gerçekleșen hasar türleri ve hasar seviyelerine göre betonarme binalarda hasar meydana gelmesinin temel sebepleri;

- Yapılaşmada zemin sınıfına dikkat edilmemesi ve yanlıș temel seçimi,

- Ticari amaçlı kullanılan zemin katlarda kolonların kesilmesi, dolgu/perde duvar kullanılmaması,

- Taşıyıcı elemanlarda düz donatı kullanılması nedeniyle yeterli aderans sağlanamaması,

- Yapılaşmada izin verilen kat adedinin aşılması ve yapıya hesaplanandan fazla sabit ve hareketli yük yüklenmesi,

- Yumuşak kat ve kolonlarda plastik mafsal oluşması gibi deprem yönetmeliğine uygun olmayan tasarımlar olarak sıralanabilir.
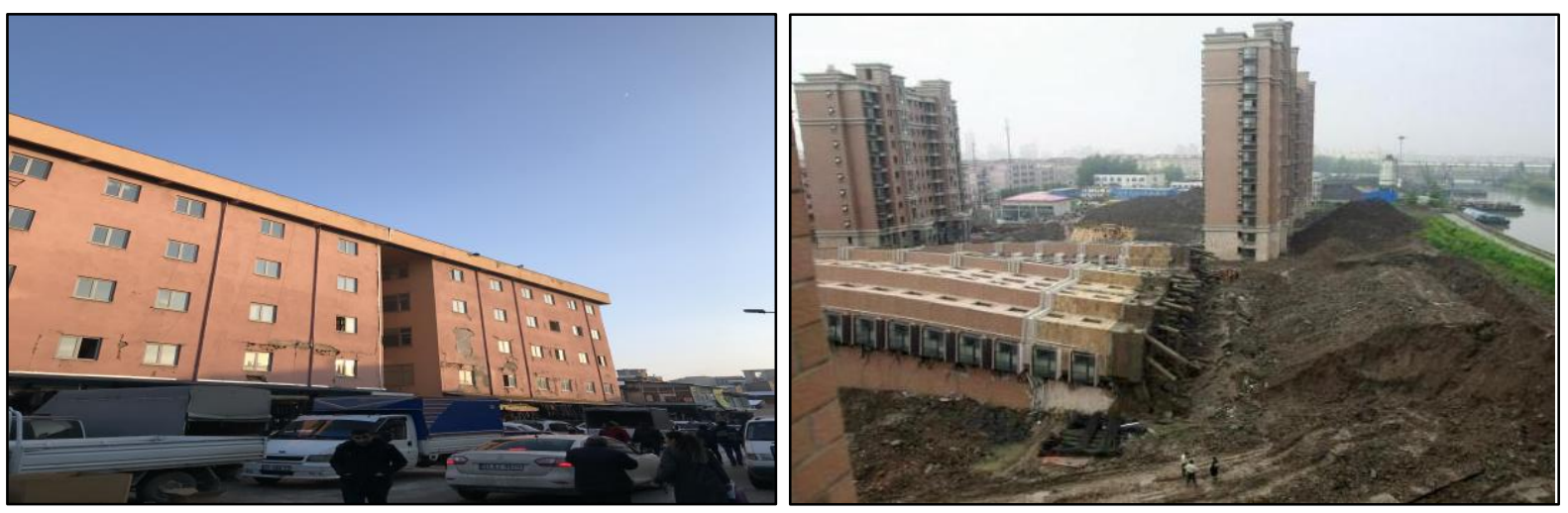

Şekil 3. Depremde taşıyıcı elemanları hasar görmüș ve zemin sıvılașması oluşmuş bina örnekleri

Onarım/güçlendirme maliyetlerinin hesabında taşıyıcı sistem hasarlarının maliyeti, taşıyıcı olmayan elemanlarda oluşan hasarların maliyeti, mekanik, sıhhi tesisat gibi bina içerik 
hasarlarının maliyetleri, acil barınma ve güçlendirme maliyetleri ile insani kayıplar olarak 5 ana başlık üzerinde maliyet tahmini yapılmıştır (Kusar vd., 2013; Yanmaz ve Luş, 2005; Williams vd. 2009; Naja ve Baytiyeh, 2014). Binaya etkiyen maliyet kalemlerinin hesaplamalarında yapısal hasarlar için bina elemanları onarım oranları, acil barınma maliyeti hesaplamalarında bina onarım süresi, kira ve taşınma maliyetleri, ölüm ve yaralanma gibi insani kayıplarda ise yaralanma oranlarından faydalanılmıştır.

Onarım/güçlendirme işlemlerinde güçlendirme perdesi imalatı, güçlendirme yapılacak taşıyıcı eleman yüzeylerinde temizlik, sıva ve boyaların dökülmesi gibi ön hazırlıklar, perde ankrajları, temel takviyesi, malzeme tanımı, makine ekipmanların belirlenmesi gibi genel hususlar, imalatların geçersiz sayılmasına neden olacak kusurlu imalatlar güçlendirme maliyetinin hesabında kullanılmıştır (Bilen, 2010; Demirkan, 2014; Yiğit, 2002).

Yapısal kayıplar; taşıyıcı ve taşıyıcı olmayan yapı elemanların yenileme maliyetleri Van İli'nde deprem güçlendirme alanında faaliyet gösteren uzman firmalardan elde edilmiștir. Söz konusu maliyetlere ilaveten onarım sürecinde yenileme harici oluşması beklenen ek kayıpların hesaplanabilmesi adına Fayda/Maliyet Analizi'nde kullanılmak üzere Tablo 3'teki onarım oranları belirlenmiştir (Ferritto, 1997). Buna göre i. hasar seviyesinde zarar gören bir yapı elemanının onarım maliyeti Denklem (1) kullanılarak tespit edilmiştir.

$$
\text { Onarım Maliyeti }(\text { TMi })=(\text { Yenileme Maliyeti }) x(\text { Onarım Oranı })
$$

Tablo 3. Yapı elemanları için onarım oranları

\begin{tabular}{lc}
\hline \multicolumn{1}{c}{ Elemanlar } & Onarım Oranı \\
\hline Taşıyıcı Eleman & 1,50 \\
\hline Mekanik Ekipman & 1,25 \\
\hline Elektrik Ekipman & 1,25 \\
\hline Mimari Eleman & 1,25 \\
\hline Asansör & 1,25 \\
\hline Bina İçeriği & 1,05 \\
\hline
\end{tabular}

İnsani kayıplar; esas olarak yapısal hasarlardan kaynaklanan insani kayıplar, hasar seviyesi ile yıkılan taşıyıcı ve taşıyıcı olmayan yapı elemanlarının ağırlıklarıyla ve deprem anında binada bulunan insan sayısı ile doğrudan ilișkilidir. Tablo 4'te belirtilen deprem ve insani kayıp ilișkisini belirleyebilmek için Denklem (2) ve Denklem (3) ile belirtilen yaralanma derecesine bağlı insani kayıp tanımlaması yapılmalıdır (URL 1). Buna göre (i) hasar seviyeleri; 1 (az), 2 (orta), 3 (ağır) ve 4 (çökme) olarak, (j) yaralanma derecesi ise; seviye 1, 2, 3 ve 4 olarak belirlenmiş olup, $\dot{I} K_{\mathrm{i}}$ ise (i) hasar seviyesi için insani kayıp maliyeti toplamını göstermektedir.

$$
(\text { Kayıp }) i i=(\text { Binadaki insan sayısı }) x(\text { Yaralanma Oranı }) i i
$$

$$
\dot{\mathrm{I}} \mathrm{K}_{\mathrm{i}}=\sum_{j}^{4}(\text { Kayıp }) i j x(\text { Yaralanma maliyeti }) j
$$

Tablo 4. İnsani kayıp tanımlamaları

\begin{tabular}{cl}
\hline Seviye & \multicolumn{1}{c}{ Açıklama } \\
\hline Seviye 1 & Temel ilkyardım gerektiren yaralanmalar \\
\hline Seviye 2 & Hastanede tedavi gerektiren fakat hayati tehlike içermeyen yaralanmalar \\
\hline Seviye 3 & $\begin{array}{l}\text { Hemen tıbbi müdahale yapılmadı̆̆ takdirde hayati tehlike içeren yaralanmalar, } \\
\text { bu tür yaralanmaların çoğu yapısal çökmeler sonucu gerçekleşmektedir }\end{array}$ \\
\hline Seviye 4 & Hemen ölüm veya ömür boyu sakat kalma durumu \\
\hline
\end{tabular}


Acil barınma maliyeti; bu maliyet türünde binanın tamamı veya bir bölümünün kullanılamaz hale gelmesi ve geçici konut kira ile taşınma maliyeti olmak üzere iki ana başlık altında incelenmesi gerekmektedir. Dolayısıyla hasar seviyeleri Denklem (4) ile gösterildiği gibi acil barınma maliyeti, bina onarım süresi, kira maliyeti ve taşınma maliyetleri ile ilişkili olarak değişebilmektedir (URL 1; Erdik ve Aydınoğlu, 2002).

$$
A B M i=(\text { Bina onarım süresi }) i x(\text { Kira maliyeti })+(\text { Taşınma maliyeti })
$$

Güçlendirme maliyeti hesabında bölgede mevcut güçlendirme proje verileri ve literatür altyapısı ile Tablo 5'teki maliyet kalemleri ortaya konulmuş ve örnek binalar üzerinden ortaya konulan metraj ve keşif çalışmaları ile maliyet tahmini tamamlanmıştır. Güçlendirme projelerinden beklenen faydanın hesabında ise her bir güçlendirme alternatifinin faydası, orijinal ve güçlendirilmiş binada muhtemel toplam maliyetlerin farkı olarak kabul edilmektedir (URL 1).

Tablo 5. Hasar seviyesi ve bina türlerine göre güçlendirme maliyetleri

\begin{tabular}{|c|c|c|c|c|c|c|}
\hline \multirow[b]{2}{*}{ Bina Türü } & \multicolumn{4}{|c|}{ Onarım Süresi (Gün) } & \multirow{2}{*}{ 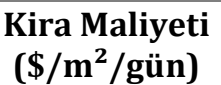 } & \multirow{2}{*}{$\begin{array}{c}\text { Taşınma Maliyeti } \\
\left(\$ / \mathbf{m}^{2}\right)\end{array}$} \\
\hline & Az Hasar & Orta Hasar & Ağır Hasar & Cökme & & \\
\hline Konut & 5 & 180 & 480 & 960 & 0,06 & 1,8 \\
\hline Hastane & 20 & 210 & 540 & 720 & 0,09 & 3,0 \\
\hline Okul & 10 & 90 & 360 & 480 & 0,09 & 2,0 \\
\hline
\end{tabular}

\subsection{Yıkım Türü ve Maliyetleri}

Literatür araştırması ve mevcut uygulamaların incelenmesi ile yıkım türleri genel olarak elle yıkım, mekanik yıkım, yapı sökümü, patlayıcı madde ile yıkım ve karma yıkım teknikleri olarak sınıflandırılmıştır (Abanuz, 2005; Koca, 2006; Tezcan, 2017). Yıkım türünün seçiminde maliyet kalemlerinin diğer yöntemlere göre daha avantajlı olduğunun görülmesi bu yöntemin seçiminde en etkili faktör olarak belirlenmiştir. Yapı söküm tekniğinde kullanılan maliyet kalemleri; şantiye kurulumu, işçilik, ekipman, nakliye ve tasfiye olarak belirlenmiştir. Her bir maliyet kalemi için yapılacak iş ve işlemler T.C. Çevre ve Şehircilik Bakanlığı birim fiyatları üzerinden ayrı ayrı belirlenmiş, metraj ve keşif çalışması ile toplam maliyet tahmini ortaya konulmuştur.

\subsection{Onarım Yıkım Maliyet Analizine İlişkin Karar Yöntemleri}

Onarım/güçlendirme veya yıkım kararının maliyetler açısından incelenmesinde güçlendirme projelerinden elde edilecek faydaların parasal değerleri ile maliyetlerin bugünkü değerleri nakit akım yöntemleri ile hesaplanmıştır. Bu yöntemler; net bugünkü değer, iç verim oranı, fayda/maliyet oranı ve geri ödeme süresi yöntemleridir (Kaplan, 2014; Tanrıvermiş, 2018). Bilimsel herhangi bir geçerliliği veya hüküm altına alınmış bir uygulama olmamasına rağmen mevcut koşullarda uygulanan güçlendirme/yıkım maliyeti oranı olan $\% 40$ uygulamasının gerek yapısal güvenlik gerekse ekonomik geçerliliği tartışılmıştır. Onarım/güçlendirme projelerinde nakit akım yöntemlerinin kullanılması nedeniyle projenin iç dinamiklerinden oluşan güçlü ve zayıf yanlar ile dış etkenler nedeniyle ortaya çıkan fırsatlar ve tehditler Tablo 6'da SWOT analizi ile belirlenmiştir.

Tablo 6. Onarım/güçlendirme projelerine ilişkin SWOT analizi

\begin{tabular}{|c|c|}
\hline \multicolumn{2}{|l|}{ SWOT ANALIZİ } \\
\hline Güçlü Yanlar & Zayıf yanlar \\
\hline $\begin{array}{l}\text { Yatırım kuruluş dönemi süresi, ekonomik ömrü, katlanılan maliyeti } \\
\text { ve beklenen süre içinde ortaya çıan net nakit akışlarının } \\
\text { planlanabilmesi }\end{array}$ & \multirow{3}{*}{$\begin{array}{lcc}\text { Analiz çlktılarının } & \text { kesin bir } \\
\text { sonuç vermemesi } & \text { nedeniyle } \\
\text { karar merciindeki } & \text { kişilerin } \\
\text { alanında bilgi sahibi bireyler } \\
\text { olması gerekliliği }\end{array}$} \\
\hline Yatırıma karşılık gelen faydaları veya getirilerin görülebilmesi & \\
\hline $\begin{array}{l}\text { Beklenen faydalar ve maliyetlerin belirlenmesiyle ileriye dönük } \\
\text { planlama yapma imkânı sağlanabilmesi }\end{array}$ & \\
\hline
\end{tabular}


Depremden Etkilenen Betonarme Konutların Onarım/Yıkım Karar Sürecine Maliyetlerin Etkisi

Projenin fizibil olup olmadığının tespit edilebilmesi

Firsatlar

Gerekli görüldüğü takdirde bölgesel şartlar, yapıya has özellikler nedeniyle farklılık arz edebilecek maliyet veya fayda kalemlerinin bu yöntemlerde kolayca karar sürecine dâhil edilebilmesi

Onarım/güçlendirme projelerinin özgün nitelikte olması nedeniyle her proje için güncelleme ve değişiklik yapma imkânı sağlaması
Tehditler

Dış etkenler ve yapı tipi her proje için farklılık göstereceğinden çlktılar üzerinden genelleme veya standartlaştırma imkânının bulunmaması

\section{BULGULAR VE TARTIŞMA}

\subsection{Hasar Türleri ve Hasar Seviyelerine İlișkin Bulgular}

İncelenen binaların plan geometrilerinin dikdörtgen veya kare tabanlı oldukları, taşıyıcı sistem tiplerinin tüm katlarda betonarme karkas olduğu, ara kat ve çatı döşemelerinin de betonarme olarak inşa edildikleri tespit edilmiştir. Taşıyıcı elemanların hasar seviyeleri ile hasarlı bina sayıları Tablo 7'de verilmiştir. Buna göre çalıșma konusu alanda ağırlıklı olarak orta ve az hasarlı binaların bulunduğu tespit edilmiştir.

Tablo 7. Taşıyıcı elemanlarda hasar seviyeleri ile hasarlı bina sayıları

\begin{tabular}{|c|c|c|c|c|c|}
\hline Grubu & Bulunduğu Kat & Hasarsız & Az Hasarlı & Orta Hasarlı & Ağır Hasarlı \\
\hline \multirow{3}{*}{ A1 } & Bodrum & 1 & 6 & 4 & - \\
\hline & Zemin & 4 & 7 & 11 & 3 \\
\hline & Diğer & 4 & 7 & 11 & 3 \\
\hline \multirow{3}{*}{ A2 } & Bodrum & 2 & 13 & 13 & 11 \\
\hline & Zemin & 2 & 15 & 31 & 13 \\
\hline & Diğer & 2 & 14 & 32 & 13 \\
\hline \multirow{3}{*}{ A3 } & Bodrum & - & - & 4 & 6 \\
\hline & Zemin & 1 & 1 & 5 & 9 \\
\hline & Diğer & 1 & 1 & 5 & 9 \\
\hline \multirow{3}{*}{ B1 } & Bodrum & 1 & - & - & - \\
\hline & Zemin & 6 & - & 1 & - \\
\hline & Diğer & 6 & - & 1 & - \\
\hline \multirow{3}{*}{ B2 } & Bodrum & 13 & 15 & 6 & 3 \\
\hline & Zemin & 13 & 19 & 12 & 4 \\
\hline & Diğer & 13 & 18 & 13 & 4 \\
\hline \multirow{3}{*}{ B3 } & Bodrum & - & 2 & 4 & - \\
\hline & Zemin & 1 & 4 & 7 & 1 \\
\hline & Diğer & 2 & 3 & 7 & 1 \\
\hline \multirow{3}{*}{ C1 } & Bodrum & - & 1 & - & - \\
\hline & Zemin & 1 & 1 & - & - \\
\hline & Diğer & - & 1 & 1 & - \\
\hline \multirow{3}{*}{ C2 } & Bodrum & 6 & 3 & - & - \\
\hline & Zemin & 8 & 4 & 4 & - \\
\hline & Diğer & 7 & 5 & 4 & - \\
\hline \multirow{3}{*}{ C3 } & Bodrum & 2 & 4 & 3 & - \\
\hline & Zemin & 3 & 14 & 6 & - \\
\hline & Diğer & 3 & 14 & 6 & - \\
\hline
\end{tabular}


1998 deprem yönetmeliğinden önce inşa edilen binaların ağır hasar yüzdelerinin sonraki yıllarda yapılan binalara göre daha fazla olduğu anlaşılmıştır. Betonarme binaların taşıyıcı elemanlarının ağır ve orta hasar yüzdelerinin yüksek olmasında özellikle zemin katta ticari amaçlı kullanılan bağımsız bölümlerde duvar ve kolonların kesilmesi, taşıyıcı elemanların yüksek kesme gerilmelerine maruz kalması, deprem etriyesi ve yönetmelik hükümlerinin uygulanmamış olması gibi kriterler belirleyici olmuştur. Diğer yandan taşıyıcı elemanların hasar gördüğü katlara bakıldığında da yine zemin katta bulunan taşıyıcı elemanların ağırlıkta olduğu tespit edilmiștir. Bunun sebebinin de yine zemin katlarda bulunan tașıyıcı elemanların ticari olarak kullanılan bağımsız bölüm kullanıcıları tarafından zarar görmesi ve deprem yönetmeliği hükümlerinin uygulanmaması olarak sıralanabilir.

Taşıyıcı olmayan elemanlarda tespit edilen hasarlı bina sayıları ile hasar seviyeleri Tablo 8'de verilmiştir. Bölme duvar, merdiven ve çatı elemanlarının incelendiği binalarda merdiven elemanlarının orta ve üzerinde bir seviyede hasar gören binalarda genellikle ilk yıkılan elemanlardan olduğu belirlenmiştir. Binalarda bölme duvarların orta ve ağır hasar seviyelerinin yüksek olduğu, yıllara göre bakıldığında dahi, değişen yönetmelik hükümlerine rağmen azalma görülmediği tespit edilmiştir. Çatı elemanları genel olarak bina ağır hasar almadığı sürece mevcut dayanımı ve özelliğini koruyabilmiştir. Bölme duvarların hasar nedenleri incelendiğinde taşıyıcı sistem elemanları ile birlikte çalışamadığı, deprem anında ayrılmalar olduğu, ayrıca hasarlı olan binalardaki bölme duvarlarda kesme çatlakları da yüksek oranda gözlenmiştir.

Tablo 8. Taşıyıcı olmayan elemanlarda hasar seviyeleri ile hasarlı bina sayıları

\begin{tabular}{|c|c|c|c|c|c|}
\hline Grubu & Eleman Adı & Hasarsız & Az Hasarlı & Orta Hasarlı & Ağır Hasarlı \\
\hline \multirow{3}{*}{ A1 } & Bölme Duvar & 2 & 10 & 10 & 3 \\
\hline & Merdiven & 14 & 0 & 0 & 11 \\
\hline & Çatı & 17 & 2 & 5 & 1 \\
\hline \multirow{3}{*}{ A2 } & Bölme Duvar & 7 & 19 & 22 & 13 \\
\hline & Merdiven & 29 & 0 & 0 & 32 \\
\hline & Çatı & 38 & 3 & 12 & 8 \\
\hline \multirow{3}{*}{ A3 } & Bölme Duvar & 0 & 4 & 7 & 5 \\
\hline & Merdiven & 3 & 0 & 0 & 13 \\
\hline & Çatı & 10 & 3 & 2 & 1 \\
\hline \multirow{3}{*}{ B1 } & Bölme Duvar & 2 & 9 & 13 & 1 \\
\hline & Merdiven & 12 & 0 & 0 & 13 \\
\hline & Çatı & 12 & 4 & 8 & 1 \\
\hline \multirow{3}{*}{ B2 } & Bölme Duvar & 1 & 24 & 15 & 8 \\
\hline & Merdiven & 20 & 0 & 0 & 28 \\
\hline & Çatı & 34 & 7 & 5 & 2 \\
\hline \multirow{3}{*}{ B3 } & Bölme Duvar & 2 & 3 & 8 & 0 \\
\hline & Merdiven & 7 & 0 & 0 & 6 \\
\hline & Çatı & 7 & 2 & 4 & 0 \\
\hline \multirow{3}{*}{$\mathrm{C1}$} & Bölme Duvar & 0 & 1 & 1 & 0 \\
\hline & Merdiven & 2 & 0 & 0 & 0 \\
\hline & Çatı & 2 & 0 & 0 & 0 \\
\hline \multirow{3}{*}{$\mathrm{C} 2$} & Bölme Duvar & 1 & 9 & 5 & 0 \\
\hline & Merdiven & 10 & 0 & 0 & 5 \\
\hline & Çatı & 12 & 0 & 3 & 0 \\
\hline
\end{tabular}


Depremden Etkilenen Betonarme Konutların Onarım/Yıkım Karar Sürecine Maliyetlerin Etkisi

\begin{tabular}{cccccc}
\hline \multirow{2}{*}{ C3 } & Bölme Duvar & 0 & 15 & 6 & 1 \\
\cline { 2 - 6 } & Merdiven & 3 & 0 & 0 & 12 \\
\cline { 2 - 6 } & Çatı & 6 & 4 & 4 & 0 \\
\hline
\end{tabular}

Binaların taşıyıcı ve taşıyıcı olmayan eleman düzeyinde ve gerekli diğer özellikleri ile birlikte incelenmesi neticesinde binalar grup kodlarına göre az, orta ve ağır hasarlı olmak üzere 3 farklı hasar seviyesinde gruplandırılmıştır. Mevcut duruma ilişkin elde edilen bulgulara göre binaların \%54,07'sinin orta ve ağır hasarlı oldukları, bu binaların önemli bir kısmının 2007 yönetmeliğinden önce yapılmış oldukları tespit edilmiştir (Tablo 9). Üzerinde durulması gereken bir diğer husus ise binalarda kat adedi arttıkça hasar oranlarının da doğru orantılı olarak arttığı gerçeğidir. Örneğin; 2-5 kat arası binalarda orta hasarlı olma durumu ortalama \%18,10, 6-7 kat arası binalarda \%37,04 ve 8-10 kat arası binalarda ise \%37,45 olarak saptanmıștır.

Tablo 9. Betonarme binaların hasar seviyeleri

\begin{tabular}{cccc}
\hline Grubu & Az Hasarlı & Orta Hasarlı & Ağır Hasarlı \\
\hline A1 & 11 & 10 & 4 \\
\hline A2 & 13 & 35 & 13 \\
\hline A3 & 2 & 5 & 9 \\
\hline B1 & 6 & 1 & 0 \\
\hline B2 & 31 & 13 & 4 \\
\hline B3 & 5 & 7 & 1 \\
\hline C1 & 2 & 0 & 0 \\
\hline C2 & 11 & 4 & 0 \\
\hline C3 & 15 & 6 & 1 \\
\hline
\end{tabular}

Genel olarak yapılarda hasar seviyelerinin değişkenlik göstermesinde 1999 ve 2007 yönetmelikleri etkili olmuştur. Ayrıca binalarda Tablo 10'da verilen bölgedeki zemin özellikleri, taşıyıcı ve taşıyıcı olmayan elemanlarda kesme kuvveti etkisiyle kırılma, ezilme, çökme, ayrılma gibi durumların gözlenmesi hasar nedenleri olarak sıralanabilir.

Tablo 10. Grup kodlarına göre hasar türleri

\begin{tabular}{|c|c|}
\hline $\begin{array}{l}\text { Grup } \\
\text { Kodu }\end{array}$ & Hasar Türü \\
\hline A1 & \multirow{3}{*}{$\begin{array}{l}\text { Taşıyıcı ve taşıyıcı olmayan elemanlarda kesme kuvvetinin etkisiyle ayrılmalar görülmesi, } \\
\text { katlarda kolon kısalması, bina köşelerinde dökülmeler ve ayrılmalar }\end{array}$} \\
\hline A2 & \\
\hline A3 & \\
\hline B1 & \multirow{3}{*}{$\begin{array}{l}\text { Beton ve donatıların dayanım yetersizliği sebebiyle taşıyıcı ve taşıyıcı olmayan elemanlarda } \\
\text { dökülme, ayrılma ve çatlakların oluşumu, kesme kuvveti etkisiyle göçme ve ayrılmaların } \\
\text { görülmesi }\end{array}$} \\
\hline B2 & \\
\hline B3 & \\
\hline C1 & \multirow{3}{*}{$\begin{array}{l}\text { Kısa kolon oluşumu, merdiven göçmesi, bölme duvarlarda kesme kuvveti, zemin } \\
\text { kirişlerinde eğilme çatlakları, } 8 \text { ve üzeri katlı binaların normal katlarında ağır duvar } \\
\text { hasarları }\end{array}$} \\
\hline $\mathrm{C} 2$ & \\
\hline C3 & \\
\hline
\end{tabular}

Hasar türlerinin oluşma nedenleri incelendiğinde yapılaşmada zemin sınıfına dikkat edilmemesi ve yanlış temel seçimi, ticari amaçlı kullanılan zemin katlarda kolonların kesilmesi, perde duvar kullanılmaması, taşıyıcı elemanlarda kullanılan düz donatı nedeniyle yeterli aderans sağlanamaması, yapılaşmada izin verilen kat adedinin aşılması ve yapıya hesaplanandan daha fazla sabit ve hareketli yük yüklenmesi, yumuşak kat oluşumu, kolonlarda plastik mafsal oluşması gibi deprem yönetmeliğine uygun olmayan tasarım yapılması hususları tespit edilmiştir. Literatürde yer alan, binalarda onarım/yıkım kararında etkili olan değiş̧kenler ile karşılaştırma yapıldığında, çalışma kapsamında yapısal yönden elde edilen bulguların beton basınç dayanımı, bölgenin depremselliği ve binadaki çatlak ve kırılmalar yönlerinden uyumlu olduğu (Yılmaz, 
2016), bununla birlikte güçlendirme/yeniden yapım oranı değişkeninin tek başına etkili olmadığı gözlenmiştir.

\subsection{Onarım ve Yıkım İşlemlerine İlişkin Bulgular}

Onarım/güçlendirme alternatiflerinin belirlenmesinde bina yaşı, kat adedi, yapıda kullanılan malzeme gibi özelliklerin yanı sıra deprem yönetmeliklerinin yürürlüğe girdiği tarihler de etkili olmuştur. Binaların yapısal özellikleri ve yaşları dikkate alındığında 2007 deprem yönetmeliğinden önce ve sonra inșa edilen binalar olarak 2 adet, binanın projesine göre olduğu gibi çözümlenmesi ve yıkılıp yeniden yapılması hususları göz önünde bulundurularak 2 adet olmak üzere toplam 4 adet bina örneği seçilmiştir.

1. Alternatif; binanın tamamen yıkılıp yeniden yapılması,

2. Alternatif; binanın projesine göre olduğu gibi çözümlenmesi,

3. Alternatif; binanın bodrum katında perde duvar ve deprem etriyeleri kullanılarak güçlendirilmesi

4. Alternatif; binanın tüm katlarında perde duvar güçlendirilmesi ve deprem etriyeleri kullanılması

Güçlendirme işlemlerinde alternatiflerin kritik hasar seviyeleri orta hasar düzeyi, bina kat adedi en çok orta hasarın meydana geldiği bodrum+zemin+4 kat olmak üzere toplam 6 kat olarak hesaplanmış olup, bina yaşı grup kodlarında belirtilen yapım tarihleri dikkate alınarak belirlenmiştir. Buna göre binaların yeniden yapım alternatifinde en çok hasar gören A grubu binalar (1972-1998), bina üzerinde herhangi bir işlem yapılmaması alternatifinde en az hasar gören grup olan C grubu binalar (2007-2011), zemin kat güçlendirme alternatifinde zemin kat hasarlarının en çok gerçekleştiği bina grubu olan C grubu yapılar (2007-2011) ve tüm katlarda güçlendirme yapılması alternatifinde ise deprem etriyesi kullanımı en az olan ve hasarlı bina sayısı en çok olan A ve B grubu yapılar (1972-1998, 1999-2006) seçilmiştir. Binalarda onarım yıkım kararının ekonomik yönden incelenmesi aşamasında literatürde yer verilen bina yaşı etkeninin (Kusar vd., 2013), çalışma konusu alanda da etkili değişkenler arasında olduğu tespit edilerek güçlendirme ve fizibilite çalışmalarında binaların yaşlarına göre gruplandırılması yoluna gidilmiştir. Seçilen alternatifler üzerinden binalarda uygulanacak güçlendirme aşamaları Tablo 11 'de değerlendirilmiş ve bu aşamada güçlendirme projelerinde yapılacak işlemler özet olarak sıralanmıştır.

Tablo 11. Güçlendirme aşamasında yapılacak işlemler

\begin{tabular}{|c|c|}
\hline $\begin{array}{c}\text { Sira } \\
\text { No }\end{array}$ & İşlemler \\
\hline \multirow{4}{*}{1} & Güçlendirme perdeleri imalatı \\
\hline & Betonarme perde ilave edilmesi \\
\hline & Perde uçlarına gelen kolonların mantolanması \\
\hline & Güçlendirme perdelerinin mevcut kiriș ve kolonlara ankre edilmesi \\
\hline \multirow{6}{*}{1.1} & Ön Hazırlıklar \\
\hline & Perde yapılacak açıklıkları çevreleyen kolon ve kirișlerin perde yüzlerindeki sıvalarının sökümü \\
\hline & Perde yerlerinde mevcut kalorifer, pis su borusu, elektrik hattı vb. sökülmesi ve yenilenmesi \\
\hline & $\begin{array}{l}\text { Perde sınırı kolon ve kiriş yüzlerinin betonarme yüzey ortaya çıkana kadar temizlenmesi ve } \\
\text { yıkanması }\end{array}$ \\
\hline & Mevcut kolon ve kiriş yüzeylerinin yeni beton ile bağlantısının sağlanabilmesi için örselenmesi \\
\hline & Örselenen yüzeylerin yeni beton ile aderans sağlayıcı malzemeler ile kaplanması \\
\hline \multirow{6}{*}{1.2} & Perde Ankrajları \\
\hline & Perde yapılacak açıklıkta imalat işleminin en alt katta başlayıp yukarı katlara doğru ilerlemesi \\
\hline & Mevcut elemanlarda yapılacak ankraj deliği çapının, eleman çapından 5mm daha geniș olması \\
\hline & Bodrum veya en alt katta açılmıș olan temellere ankraj delikleri açılması \\
\hline & Açılan delik içlerinin basınçlı hava ile tozdan ve yabancı maddelerden arındırılması \\
\hline & Ankraj çubuklarının akıșkan kıvamlı epoksi harcı ile deliklere ekilmesi \\
\hline
\end{tabular}


Temel Takviyesi

Mevcut yapıya ait temel üzerinde, içinde veya yan yüzlerinde yer alan ve yeni imal edilecek perdelerin altına denk gelen yerlerde döşeme kaplaması, grobeton, dolgu betonu gibi kısımların kırılması ve sökümü, dolgu toprağı, mıcır gibi dolgu malzemesinin kazılarak boșaltılması

Temel takviyesi yapılacak kısımlarda kazı yapılması

Oturmayı engellemek için temel yanlarının eleküstü malzeme ile doldurulması

Kazı yapılacak alan içinde kalan her türlü kaplamanın derz kesme makinesi ile kesilerek, birleşik olduğu kısımlardan ayrılması, daha sonra kazı/kırım işleminin gerçekleştirilmesi

2 Bina dışında yapılacak kazılarda, asfalt veya beton olan yerlerde kazı sınırının derz kesme makinesi ile kesildikten sonra kazı işlemine başlanması

Takviye işlemi tamamlandıktan sonra bozulan kısımların tekrar tamir edilmesi

Grobeton, dolgu beton kırım işinin elektrik darbeli matkap, hava basınçlı kırım tabancası ile yapımı

Kırımı yapılan moloz parçaları ve kazı işleri neticesinde ortaya çıkan toprak mıcır, tüvenan gibi malzemelerin döküm sahasına nakledilmesi

Kazı yapılırken mevcut temellerin alt kotundan daha aşağı seviyelere inilmemesi, aksi durumda temellerin $45^{\circ}$ lik basınç etki alanına girilmemesi.

Genel Hususlar

İmalat tariflerinde bahsi geçen epoksi malzemesinin kartuş epoksi ürünleri olarak kullanılması

İlave betonarme perdelerin ve mantolanacak kolonlar ile mevcut taşıyıcı sisteme ait elemanların arakesit yüzeylerindeki tüm sıva ve örtü beton (paspayı) tabakalarının sökülmesi

Tabaka sökümünün darbeli matkap, kırıcı gibi aletler ile yapılması, mevcut elemanlara hasar verebilecek balyoz, çekiç benzeri aletlerin kullanılmaması

3 İlave elemanlar ile mevcut taşıyıcı sisteme ait elemanlar arasında sürtünme yüzeyi oluşturmak amacı ile darbeli matkap, kırıcı gibi aletler ile yüzey pürüzlendirmesi yapılması

Ankraj deliklerinin, güçlendirme uygulama projesinde belirtilen boyutlara ve yerlere göre mevcut donatıyı kesmeden darbeli matkap yardımıyla açılması

Ankraj delik içlerinin basınçlı hava ile tozdan arındırıldıktan sonra filiz ekimi yapılması

Filiz ekimi için hazır karışımlı kartuş epoksi malzeme kullanılması

Filiz ekiminin temelden başlamak üzere üst katlara doğru sırayla yapılması

Kusurlu İmalatlar

Ankraj filizinin çekme deneyi sırasında uygulanması gereken çekme kuvvetine ulaşmadan yapıştırma malzemesinden sıyrılması durumu. (Yapıștırma malzemesinin hatalı olması)

4 Ankraj filizinin çekme deneyi sırasında uygulanması gereken çekme kuvvetine ulaşmadan yapıştırma malzemesi ile birlikte ankraj deliğindeki mevcut betonda deformasyon oluşmadan ankraj deliğinden sıyrılma durumu. (Filiz ekimi öncesi ankraj deliği içinin tozdan arındırılmamış olması durumu)

Onarım/güçlendirme veya yıkım kararına ilişkin güçlendirme alternatiflerinin maliyet tahmininde; T.C. Çevre ve Şehircilik Bakanlığı ile T.C. Millî Savunma Bakanlığı tarafından ayrı ayrı yayımlanan 2019 yılı birim fiyat listeleri kullanılmıștır. Tablo 12'de verilen birim fiyat listesinden hasar türlerine ilişkin maliyet kalemleri içinde en büyük payı \%33,52 ile ince ve kalın donatı imalatı, sonrasında \%15,81 ile düz yüzeyli beton ve betonarme kalıbı ve üçüncü olarak da \%15,65 ile kendiliğinden yerleșen beton almaktadır. Kazı işleri, dolgu yapılması, demirsiz beton imalatı, patlayıcı kullanmadan beton ve betonarme elemanların yıkılması, kalıp iskelesi kurulması imalatları ise toplam güçlendirme maliyetleri arasında \%1'in altında etki etmiştir.

Tablo 12. Keşif ve metraj çalışması ile yaklaşık güçlendirme maliyeti

\begin{tabular}{llcccc}
\hline \multicolumn{1}{c}{ Poz No } & \multicolumn{1}{c}{ İşin Adı } & $\begin{array}{c}\text { Biri } \\
\mathbf{m}\end{array}$ & Miktar & $\begin{array}{c}\text { Birim } \\
\text { Fiyat } \\
\text { (TL) }\end{array}$ & $\begin{array}{c}\text { Toplam } \\
\text { Fiyat } \\
\text { (TL) }\end{array}$ \\
\hline $\mathbf{1 4 . 0 1 2 / 1}$ & El ile yumuşak - sert toprak kazılması & $\mathrm{m}^{3}$ & 6,32 & 53,93 & 340,99 \\
\hline $\mathbf{1 5 . 1 4 0 / 4}$ & Dolgu yapılması & $\mathrm{m}^{3}$ & 4,56 & 19,18 & 87,37 \\
\hline $\mathbf{1 6 . 0 0 3 / M K}$ & 250 Doz demirsiz beton & $\mathrm{m}^{3}$ & 2,66 & 97,64 & 259,48 \\
\hline $\mathbf{1 8 . 1 8 3}$ & Pat. mad. kullanmadan kar. inş. ylk.(duvar) & $\mathrm{m}^{3}$ & 29,90 & 35,63 & $1.065,39$ \\
\hline
\end{tabular}




\begin{tabular}{|c|c|c|c|c|c|}
\hline 18.185 & Pat. mad. kullanmadan bet. inş. yık. & $\mathrm{m}^{3}$ & 5,32 & 73,63 & 391,35 \\
\hline $21.017 / 1$ & Düz yüzeyli beton ve betonarme kalıbı & $\mathrm{m}^{2}$ & 460,62 & 54,95 & $25.310,81$ \\
\hline 21.054 A-TAK & En yüksek noktası 4 m olan kalıp iskelesi & $\mathrm{m}^{3}$ & 162,16 & 7,89 & $1.279,48$ \\
\hline 23.014-ТАK & $\emptyset 8$ - Ø12 Nervürlü inşaat demiri & ton & 6,02 & $4.029,78$ & $24.244,56$ \\
\hline 23.015-ТАK & $\emptyset 14$ - Ø28 Nervürlü inşaat demiri & ton & 7,42 & $3.965,28$ & $29.427,73$ \\
\hline MSB 153 & Bozuk betonarme yüzeylerin temizlenmesi & $\mathrm{m}^{2}$ & 156,54 & 11,88 & $1.859,71$ \\
\hline MSB 154 & Donatıları korozyona karşı koruma & $\mathrm{mt}$ & 521,80 & 16,59 & $8.656,74$ \\
\hline MSB 155 & Polimer astar & $\mathrm{m}^{2}$ & 156,54 & 19,95 & $3.123,00$ \\
\hline MSB 157 & Epoxy enjeksiyon ile çatlak tamiri & $\mathrm{mt}$ & 12,03 & 967,71 & $11.636,71$ \\
\hline MSB 158 & Paspayının kırılarak donatının açığa çıkarılması & $\mathrm{m}^{2}$ & 156,54 & 86,25 & $13.501,70$ \\
\hline MSB 324 & Kendiliğinden yerleşen beton & $\mathrm{m}^{3}$ & 61,01 & 410,71 & $25.055,46$ \\
\hline MSB 678/A1 & $\emptyset 12$ Düz veya nervürlü demirle epoksi ile filiz ekimi & Adet & 356,90 & 10,01 & $3.572,59$ \\
\hline MSB 678/C & Ø16 Düz veya nervürlü demirle epoksi ile filiz ekimi & Adet & 440,12 & 11,51 & $5.065,72$ \\
\hline MSB 678/D & $\emptyset 18$ Düz veya nervürlü demirle epoksi ile filiz ekimi & Adet & 160,17 & 13,29 & $2.128,70$ \\
\hline MSB 678/F & Ø22 Düz veya nervürlü demirle epoksi ile filiz ekimi & Adet & 208,27 & 14,89 & $3.101,18$ \\
\hline \multicolumn{4}{|c|}{ Toplam } & TL & $160.108,66$ \\
\hline & & & & USD & $26.684,78$ \\
\hline
\end{tabular}

\subsection{Onarım ve Yıkım Verilerinin Analizi}

Onarım/yıkım kararı sürecine ilişkin maliyet kalemlerinin her bir alternatif için varsayımları Tablo 13'te irdelenmiştir. Maliyet kalemleri; bina elemanları onarım maliyeti, insani kayıplar, acil barınma ve güçlendirme maliyetleri olarak dört başlık altında toplanmıştır. Bina elemanları onarım maliyeti ve insani kayıplar HAZUS verilerine göre (URL 1) acil barınma maliyeti altında incelenen kira ve taşınma maliyetleri; bölgede kira bedeli ve taşınma maliyetlerine yönelik olarak yapılan piyasa verilerine göre ve güçlendirme maliyetleri ise örnek olarak seçilen iki adet binanın güçlendirme projeleri ile metraj ve keşif çalışmaları sonucunda belirlenmiştir.

Tablo 13. Nakit akışlarda kullanılan varsayımlar

\begin{tabular}{|c|c|}
\hline Varsayımlar & Açıklamalar \\
\hline Kullanılan Para Birimi ve Kuru & Dolar $(\$)-6 \mathrm{TL} / \$$ \\
\hline Mahkeme Kararlarına Göre Yaralanma Maliyeti & 4.166,67 \$/kişi \\
\hline Binada ikamet eden kişi sayısı & 40 \\
\hline Bina kat adedi ve toplam alanı & Bodrum+Zemin +4 Kat $-1.600,00 \mathrm{~m}^{2}$ \\
\hline Mahrum kalınan birim kira geliri & $18 \$ / \mathrm{m}^{2}$ \\
\hline Mahrum kalınan kira geliri katsayıları & $\begin{array}{c}\text { Alternatif-II }(0,9) \text {, Alternatif-III }(1,0), \\
\text { Alternatif-IV }(1,1)\end{array}$ \\
\hline Taşınma maliyeti & Gidiş ve dönüş olarak iki kez hesaplanmıștır \\
\hline $\begin{array}{l}\text { Bina elemanları (taşıyıcı eleman, mekanik- } \\
\text { elektrik ekipman, asansör vs) birim onarım } \\
\text { maliyeti }\end{array}$ & $18,8 \$ / \mathrm{m}^{2}$ \\
\hline Onarım süresi & 180 gün \\
\hline Onarım sırasında kira birim maliyeti & $0,05 \$ / \mathrm{m}^{2} /$ gün \\
\hline Taşınma maliyeti & $6 \$ / \mathrm{m}^{2}$ \\
\hline Bina ömrü & 50 yil \\
\hline Yeniden yapım maliyeti & $322.666,67 \$$ \\
\hline Borç (Dış kaynak kullanımı) & $80 \%$ \\
\hline Dolara göre faiz, iskonto ve enflasyon oranları & $\% 2-\% 3,5$ ile $\% 6$ arası $-\% 4$ \\
\hline Kredi Vadesi & 10 yll \\
\hline
\end{tabular}


Alternatiflere göre bina doluluk katsayıları

\section{Yatırım dönemi ve nakit akıș süresi}

Alternatif-I; ilk yıl 0,95, sonraki yllar 0,98

Alternatif-II; 1. yll 0,6, 2. yll 0,5, 3. yll 0,1 ve sonraki yıllar 0

Alternatif-III; 1. yll 0,8, 2. yll 0,9, 3. yll 0,92, sonraki yllar 0,96

Alternatif-IV; ilk yıl 0,94, sonraki yıllar 0,96

Belirlenen maliyet kalemleri ile birlikte güçlendirme projelerinin Fayda/Maliyet Analizi için öncelikle nakit akım tabloları oluşturulmuştur. Nakit akım tablolarında kullanılan varsayımlar ile belirlenen iskonto oranlarına göre serbest nakit akımların net bugünkü değerleri, net nakit akımlarının net bugünkü değerleri, Tablo 14'te kârlılık endeksi, Tablo 15'te iç verim oranı ve Tablo 16 'da ise nakit akıma bağlanmış geri ödeme süreleri ölçütleri hesaplanarak her bir alternatif için karşılaştırma yapılmıştır.

İskonto oranının \%3,5 ile \%6,0 arasında değișen oranlarda alınması durumunda, I. alternatif için nakit akımlarının bugünkü değerinin 15.954 \$ ile 109.409 \$ arasında, III. alternatif için 13.602 \$ ile 69.986 arasında ve IV. alternatif için ise 337,00 \$ ile 72.474 \$ arasında değiștiği, I. alternatifte $\% 3,5$ ile $\% 6,0$ arasındaki iskonto oranlarında 12 yıla kadar olan değerlerin, II. alternatifte \%3,5 ile $\% 6,0$ arasındaki tüm iskonto oranı değerlerinin, III. alternatifte tüm iskonto oranları için ilk iki yıldaki nakit akımlarının ve IV. alternatifte tüm iskonto oranlarında ilk 4 yıl için nakit akımların net bugünkü değerinin negatif olduğu tespit edilmiştir. Çalışmanın yapıldığı zaman aralığında geçerli ekonomik ve finansal koşullar ile geleceğe yönelik öngörüler çerçevesinde iskonto oranının \%3,5 ile \%5 arasında alınması durumunda, net bugünkü değer ölçütüne göre proje alternatiflerinin mali sonuçlarının kabul edilebilir olduğu ortaya çıkmaktadır. Elde edilen sonuçlar literatür çalışmaları ile karşılaştırıldığında karlılık endeksi sonuçlarının tutarlı olduğu görülmüş olup (Boylu, 2005), bununla birlikte iç verim oranı ve geri ödeme süreleri yöntemleri ile de geliştirilmiştir.

Tablo 14. Kârlılık endekslerinin karşılaştırılması

\begin{tabular}{ccccc}
\hline İskonto Oranı (\%) & Alternatif-I & Alternatif-II & Alternatif-III & Alternatif-IV \\
\hline $\mathbf{3 , 5}$ & 0,91 & 0,00 & 5,01 & 1,16 \\
\hline $\mathbf{4 , 0}$ & 0,81 & 0,00 & 4,64 & 1,05 \\
\hline $\mathbf{4 , 5}$ & 0,72 & 0,00 & 4,31 & 0,96 \\
\hline $\mathbf{5 , 0}$ & 0,64 & 0,00 & 4,00 & 0,87 \\
\hline $\mathbf{5 , 5}$ & 0,57 & 0,00 & 3,73 & 0,80 \\
\hline $\mathbf{6 , 0}$ & 0,51 & 0,00 & 3,48 & 0,73 \\
\hline
\end{tabular}

Tablo 15. İç verim oranlarının karşılaştırılması

\begin{tabular}{cccc}
\hline Alternatif-I & Alternatif-II & Alternatif-III & Alternatif-IV \\
\hline$\% 5,70$ & $\% 0,00$ & $\% 22,30$ & $\% 7,50$ \\
\hline
\end{tabular}

Tablo 16. Geri ödeme sürelerinin karşılaştırılması

\begin{tabular}{|c|c|c|c|c|}
\hline $\begin{array}{l}\text { İskonto Oranı } \\
\text { (\%) }\end{array}$ & Alternatif-I & Alternatif-II & Alternatif-III & Alternatif-IV \\
\hline 3,5 & 27 yıl 5 ay & \multirow{6}{*}{$\begin{array}{l}\text { Vade boyunca geri } \\
\text { ödeme alınamamıştır. }\end{array}$} & 7 yll 6 ay & 24 yll 5 ay \\
\hline 4,0 & 28 yll 9 ay & & 7 yll 7 ay & 25 yıl 6 ay \\
\hline 4,5 & 30 yll 5 ay & & 7 yll 8 ay & 26 yll 8 ay \\
\hline 5,0 & \multirow{3}{*}{$\begin{array}{l}\text { Vade boyunca geri ödeme } \\
\text { alınamamıştır. }\end{array}$} & & 7 yll 9 ay & $28 \mathrm{yll}$ \\
\hline 5,5 & & & 7 yll 11 ay & 29 yll 8 ay \\
\hline 6,0 & & & 7 yll 12 ay & 31 yll 7 ay \\
\hline
\end{tabular}


Yatırım analizinde mümkün olduğunca bugünkü değeri ve karlılık endeksi yüksek olan ve nakit akıma bağlanmış geri ödeme süresi en düşük olan ve son olarak iç verim oranı, ortalama sermaye maliyeti veya iskonto oranından en yüksek olan seçeneğe odaklanılması, kaynak kullanım etkinliği açısından önemli görülmektedir. Belirtilen proje alternatiflerinde iskonto oranı olarak sırasıyla \%3,5 ile \%6,0 arasında değișen oranlarda alınması halinde, serbest nakit akımlarının net bugünkü değerleri, kârlılık endeksi, iç verim oranı ve nakit akıma bağlanmış geri ödeme süresi yöntemlerine göre elde edilen sonuçların, geleneksel nakit akım analizi ile hemen hemen aynı olduğu tespit edilmiştir. Serbest nakit akım analizinin sonuçlarına göre güçlendirme proje alternatifleri kapsamında inşa edilecek ve işletilecek projeler için yapılan yatırım ve faydanın, en fazla 3. alternatif üzerinde yoğunlaştığı ve yatırımın geri kazanım süresinin ise 7,5 yılda sağlanabileceği ortaya çıkmaktadır. Burada projeyi gerçekleştirecek firma veya idarenin hem projeye bağlanan sermayesini hem de asgari ölçüde proje ve geliştirici kârı ile genel yönetim giderlerini geri kazanmakta ve sağlanabilecek kârlılık oranının da sermayenin alternatif maliyetinden nispeten daha yüksek bulunduğu tespit edilmiştir. Buna ilave olarak uygulamada güçlendirme/yıkım kararı verilebilmesine ilişkin yaygın olarak kullanılan \%40 maliyet oranı ile Tablo 17'de elde edilen veriler karşılaştırılmıştır.

Tablo 17. Güçlendirme/yıkım maliyeti oranlarının karşılaştırılması

\begin{tabular}{lccc}
\hline \multicolumn{1}{c}{ Alternatif } & Güçlendirme Maliyeti (\$) & Yeniden Yapım Maliyeti (\$) & Oran (\%) \\
\hline $\begin{array}{lccc}\text { Zemin kat güçlendirmesi } \\
\text { (C grubu binalar) }\end{array}$ & $89.000,00$ & & 27,58 \\
\hline $\begin{array}{l}\text { Tüm katların güçlendirmesi } \\
\text { (A ve B grubu binalar) }\end{array}$ & $247.522,00$ & $322.666,67$ & 76,71 \\
\hline
\end{tabular}

\section{SONUÇ VE ÖNERİLER}

İnceleme sonuçlarına göre proje alternatiflerinde iskonto oranının sırasıyla \%3,5-6 arasında değișen oranlarda alınması halinde serbest nakit akışların net bugünkü değerlerinde kârlılık endeksi, iç verim oranı ve nakit akıma bağlanmış geri ödeme süresi yöntemlerine göre elde edilen sonuçların, geleneksel nakit akış analizi ile benzer olduğu tespit edilmiştir. Serbest nakit akış analizi sonuçlarına göre inşa edilecek ve işletilecek projeler için yapılan yatırım ve elde edilecek faydanın, en fazla III. alternatif olan zemin kat güçlendirmesi yapılan C grubu binalar üzerinde yoğunlaştığı ve 7,5 yılda yatırımın geri dönüş sağlayabileceği hesaplanmıştır. Burada projeyi gerçekleştirecek firma veya idarenin hem projeye bağlanan sermayesini hem de asgari ölçüde proje ve geliştirici karı ile genel yönetim giderlerini geri kazanmakta ve sağlanabilecek karlılık oranının da sermayenin alternatif maliyetinden nispeten daha yüksek bulunduğu belirlenmiștir.

Afet nedeniyle hasar görmüş binalarda sıkça karşılaşılan, ancak yeterli bilimsel temelinin olmadığı gözlenen güçlendirme/yıkım maliyetinin \%40 oranına göre yıkım veya güçlendirme kararı verilmesi hususu çalışma kapsamında karşılaştırma yapılarak değerlendirilmiştir. Yalnızca zemin katta güçlendirme yapılması planlanan III. alternatifin (C grubu binalar) \%27,58 ile söz konusu oranın altında ve tüm katlarda güçlendirilme yapılan IV. alternatifin (A ve B grubu binalar) ise \%76,71 ile söz konusu oranın üzerinde olduğu görülmüştür.

Ayrıca literatürde yer alan söz konusu oranın karşılaştırılmasına yönelik çalışmalarda da bu oranın onarım/yıkım karar sürecinde tek başına etkili olmasının doğru olmayacağı teyit edilmiştir. Ancak özellikle afet nedeniyle hasar gören binaların onarım/güçlendirme kararının aynı zamanda sosyal devlet anlayışının bir gereği olması ve kamunun kâr amacı gütmeyen yapısı nedeniyle ihtiyaç halinde geri ödeme süresi, kârlılık endeksi ve iç verim oranına bakılmaksızın söz konusu kararın verilmesi yoluna gidilebilmektedir. Bu kapsamda bakıldığında binaların güçlendirme/yeniden yapım maliyet oranı olan \%40 oranının karar vermede sabit bir oran olarak kullanımı gerçekçi sonuçlar ile çelişmektedir. 
Yatırım kararlarının değerlendirilmesinde kullanılan fayda maliyet analizi yönteminin yanı sıra araştırma alanının bölgesel düzeyde bir kenti, daha büyük ölçekte ise bütün ülkeyi etkilemesi nedeniyle, ileriki çalışmalarda ulusal ölçekte sosyal fayda maliyet analizi yöntemi de kullanılarak daha geniş ölçekli karşılaştırma yapılması yararlı olacaktır. Böylece yatırım projesinin ulusal ölçekte katma değer, istihdam, ödemeler dengesi ve gelir dağılımı ölçütleri bakımından değerlendirilmesi yapılacak ve karşılaştırma yapılırken daha geniş bir açıdan bakılabilmesine olanak sağlanacaktır.

\section{KAYNAKLAR}

Abanuz, F. (2005). Eskimiş betonarme yıkımın planlanması, Yüksek lisans tezi, İstanbul Teknik Üniversitesi, Fen Bilimleri Enstitüsü, İstanbul, Türkiye.

Alku, Ö., Z. (2005). Depremlerde hasar gören yığma ve betonarme binaların onarımı ve güçlendirilmesi, İnşaat Mühendisleri Odası İzmir Şubesi Bülteni, 125, 20-29.

Arıkan, M., Sucuoğlu, H., ve Macit, G. (2005). Economic assessment of the seismic retrofitting of low-cost apartment buildings. Journal of earthquake engineering, 9(04), 577-584, DOI: DOI:10.1080/13632460509350556

Baggio, C., Bernardini, A., Colozza, R., Corazza, L., Della Bella, M., Di Pasquale, G., Dolce, M., Goretti, A., Martinelli, A., Orsini, G., Papa, F. and Zuccaro, G. (2007). Field manual for post-earthquake damage and safety assessment and short term countermeasures (AeDES). European Communities, Lüksemburg.

Bilen, S. (2010). 2007 Deprem Yönetmeliği'ne göre bir güçlendirme uygulaması, Yüksek lisans tezi, Eskișehir Osmangazi Üniversitesi, Fen Bilimleri Enstitüsü, Eskişehir, Türkiye.

Birand, A. (2007). Temel zemin etkileşmesi; oturma ve yapı hasarı. Yapı ve Zemin Dergisi, 2(4), 11-33.

Boylu, M. (2005). A benefit/cost analysis for the seismic rehabilitation of existing reinforced concrete buildings in İzmir, Yüksek lisans tezi, İzmir Yüksek Teknoloji Enstitüsü, Mühendislik ve Fen Bilimleri Enstitüsü, İzmir, Türkiye.

Coelho, A., ve de Brito, J. (2011). Economic analysis of conventional versus selective demolition-A case study. Resources, Conservation and Recycling, 55(3), 382-392, DOI: 10.1016/j.resconrec.2010.11.003

Demirkan, D. (2014). Betonarme yapılarda onarım ve güçlendirme yöntemleri, Yüksek lisans tezi, Aksaray Üniversitesi, Fen Bilimleri Enstitüsü, Aksaray, Türkiye.

Doğan, O. (2013). Multistage seismic assessment methods for existing reinforced concrete buildings and their applicability for retrofitting cos estimation, Yüksek lisans tezi, Orta Doğu Teknik Üniversitesi, Fen Bilimleri Enstitüsü, Ankara, Türkiye.

Elibol, O. (2001). 17 Ağustos depreminin ekonomik boyutları ile orta hasarlı binaların onarım-güçlendirme maliyet analizleri ve uygulamaları, Yüksek lisans tezi, İstanbul Teknik Üniversitesi, Fen Bilimleri Enstitüsü, İstanbul, Türkiye.

Erdik, M., ve Aydınoğlu, N. (2002). Earthquake performance and vulnerability of buildings in Turkey. The World Bank Group Disaster Management Facility Report.

Ferritto, J. M. (1997). Economic analysis procedure for earthquake hazard mitigation. Facilities Engineering Service Center Port Hueneme CA.

Grünthal, G. (Ed.) (1998). Conseil De L'Europe Cahiers du Centre Europeen de Geodynamique et de Seismologie. European Macroseismic Scale, Lüksemburg. 
Güneş, S. (2018). Betonarme binalarda deprem sigortalarına esas teşkil edecek hasar seviyesi kriterlerinin belirlenmesi, Yayımlanmamış yüksek lisans semineri, Ankara Üniversitesi Fen Bilimleri Enstitüsü, Ankara, Türkiye.

Güney, D. (2011). 23 Ekim 2011 Van Depremi teknik inceleme raporu. Yıldız Teknik Üniversitesi, İstanbul.

İncir, A., Doğan, A., Duran, A., İlki, A., Yazgan, A., U., Kocaman, C., Demir, C., Cömert, M., Atıcı, N., Bayülke, N., Bostancı, Ö., Pirli, T. (2016). Depremin Etkilediği Betonarme ve Yığma Binalarda Hasar Tespiti. İnşaat Mühendisleri Odası, Ankara.

Kaminosono, T., Kumazawa, F., ve Nakano, Y. (2002). Quick Inspection Manual for Damaged Reinforced Concrete Buildings Due to Earthquakes. Based on the Disaster of 1999 Kocaeli Earthquake in Turkey, National Institute of Land and Infrastructure Management. Japonya.

Kaplan, Z. (2014). Yatırım projelerinde sosyal fayda - maliyet analizi ve örnek uygulama, Yüksek lisans tezi, Gazi Üniversitesi, Fen Bilimleri Enstitüsü, Ankara, Türkiye.

Koca, O. (2006). Patlayıcı maddelerle kontrollü yapı yıkımı, Yüksek lisans tezi, İstanbul Teknik Üniversitesi, Fen Bilimleri Enstitüsü, İstanbul, Türkiye.

Kušar, M., Kovač, M. Š., ve Šelih, J. (2013). Selection of efficient retrofit scenarios for public buildings. Procedia Engineering, 57, 651-656, DOI: 10.1016/j.proeng.2013.04.082

Naja, M. K., ve Baytiyeh, H. (2014). Towards safer public school buildings in Lebanon: An advocacy for seismic retrofitting initiative. International journal of disaster risk reduction, 8, 158-165, DOI: 10.1016/j.ijdrr.2014.03.005

Pun, S. K., Liu, C., ve Langston, C. (2006). Case study of demolition costs of residential buildings. Construction management and economics, 24(9), 967-976, DOI: 10.1080/01446190500512024

Tanrıvermiş, H. (2018). Gayrimenkul değerleme esasları, Sermaye Piyasası Lisanslama Sicil ve Eğitim Kuruluşu, Ankara.

TMMOB Mimarlar Odası. (2012). Van Depremi hasar tespit raporu. Türk Mühendis ve Mimar Odaları Birliği, Ankara.

Tezcan, D. (2017). Betonarme bina yıkım teknikleri seçiminde etkili olan parametrelerin incelenmesi: Konya Bölge Müdürlügü lojman binası örneği, Uzmanlık tezi, İller Bankası A.Ş., Konya, Türkiye.

URL 1, https://www.fema.gov/hazus-mh-user-technical-manuals (Last Acceded: 17.09.2021)

Williams, R. J., Gardoni, P., ve Bracci, J. M. (2009). Decision analysis for seismic retrofit of structures. Structural Safety, 31(2), 188-196, DOI: 10.1016/j.strusafe.2008.06.017

Yakut, A., Binici, B., Canbay, E., Erberik, A., Askan, A., Caner, A., Sarıtaş, A., Demirel, İ., O., Erdil, B., Ay, Ö., Özçelik, R., Akansel, V., H., Kale, Ö., Okuyucu, D. (2011). 23 Ekim 2011 Mw 7.2 Van Depremi sismik ve yapısal hasara ilişkin saha gözlemleri raporu. Orta Doğu Teknik Üniversitesi, Deprem Mühendisliği Araştırma Merkezi, Ankara.

Yanmaz, Ö., ve Luş, H. (2005). Yapı güçlendirme yöntemlerinin fayda-maliyet analizi. İMO Teknik Dergi, 233, 3497-3522.

Yılmaz, G., Umu, S., U. (2018). Yapılarda hasar betonarme yapı hasarları, Yapılarda hasar ders notları, Bilecik Üniversitesi, Bilecik.

Yılmaz, Z. (2016). Güçlendirme/yıkım-yapım kararının belirlenmesine yönelik bir model önerisi, Doktora tezi, Karadeniz Teknik Üniversitesi, Fen Bilimleri Enstitüsü, Trabzon, Türkiye. 
Yılmaz, Z., Çankaya, F., ve Karakaya, A. (2018). Bina maliyet oranı ve bina güçlendirme maliyetini etkileyen faktörler arasındaki ilişki. Erciyes Üniversitesi İktisadi ve İdari Bilimler Fakültesi Dergisi, (51), 151-174, DOI: $10.18070 /$ erciyesiibd.305352

Yiğit, Y. (2002). Betonarme yapılarda onarım ve güçlendirme yöntemleri ve bir güçlendirme uygulaması, Yüksek lisans tezi, İstanbul Teknik Üniversitesi, Fen Bilimleri Enstitüsü, İstanbul, Türkiye.

Yüksel, İ. (2008). Betonarme Binaların Deprem Sonrası Acil Hasar Değerlendirmeleri. Erciyes Üniversitesi Fen Bilimleri Enstitüsü Fen Bilimleri Dergisi, 24(1), 260-276. 